\title{
Increased Cyclic AMP Levels and $\beta$-Adrenergic Antagonist Binding in Cystic Fibrosis Fibroblasts
}

\author{
Jasna Markovac, ${ }^{*}$ Robert P. Erickson,$* \cdot \dagger$ and Virginia Hieber ${ }^{\dagger}$ \\ ${ }^{*}$ Department of Human Genetics and $\dagger$ Department of Pediatrics, University of Michigan \\ Medical School, Ann Arbor, Michigan 48109
}

Received March 2, 1981

The possibility of altered $\beta$-adrenergic receptors and/or adenyl cyclase activity in fibroblasts from patients with cystic fibrosis (CF) has been raised by several groups of investigators. Buchwald (1) reported a greater increase in $\mathrm{CAMP}^{1}$ after isoproterenol stimulation in CF than in normal fibroblasts and this was confirmed by Roscher et al. (2) for CF and normal fibroblasts in fresh medium. Furthermore, CF fibroblasts were shown to be more resistant to the cytotoxic effects of exogenous dibutyrl cAMP or isoproterenol than were normal fibroblasts (3). However, Buchwald and Mapelson (4) and Davis et al. (5) could not reproduce these differences in response to isoproterenol between $\mathrm{CF}$ and normal cultured skin fibroblasts. The cAMP response of fibroblasts to isoproterenol is known to be highly sensitive to time and cell density in culture (6) and the negative reports on differences between $C F$ and normal fibroblasts $(4,5)$ noted high day-to-day variability. We have studied the response to metaproterenol (a congener of isoproterenol) of pairs of CF and normal fibroblast strains compared blind on the same day and found greater responses in the $\mathrm{CF}$ strains. We have sought the basis for this difference by measuring $\beta$-adrenergic receptors and find increased binding capacity for a $\beta$-adrenergic antagonist.

\section{METHODS}

Fibroblasts were obtained either from the Human Genetics Mutant Cell Repository or from patients at the University of Michigan Hospital. The cell lines were grown as monolayers at $37^{\circ} \mathrm{C}$ in $5 \% \mathrm{CO}_{2}$ in polystyrene tissue culture flasks (obtained from Corning). Eagle's basal medium with

'Abbreviations used: cAMP, adenosine cyclic 3',5'-monophosphate; $C F$, cystic fibrosis; [ $\left.{ }^{3} \mathrm{H}\right] \mathrm{DHA},\left[{ }^{3} \mathrm{H}\right]$ dihydroalprenolol; $\mathrm{N}$, normal control. 
Earle's salts was supplemented with $10 \%$ bobby calf serum, glutamine (30 $\mathrm{mg} / 100 \mathrm{ml}$ ), and $1 \%$ penicillin-streptomycin (all from Gibco). The cells were fed every 4 days and split approximately once a week.

The cultured skin fibroblasts or amniocentesis-derived cells were treated with $10^{-5} \mathrm{M}$ metaproterenol for $30 \mathrm{~min}$. The medium was decanted leaving $0.5 \mathrm{ml}$ and cells were rapidly $(<30 \mathrm{sec})$ scraped with a rubber policeman. Aliquots were immediately pipetted into centrifuge tubes positioned in a boiling water bath and heated at $97^{\circ} \mathrm{C}$ for $10 \mathrm{~min}$. The tubes were cooled to $0^{\circ} \mathrm{C}$ and centrifuged at $800 \mathrm{~g}$ for $15 \mathrm{~min}$ and aliquots of the supernatant fluid were assayed for cAMP by the Gilman proteinbinding method (7) while the pellet was analyzed for protein by the method of Lowry et al. (8). The cross-reactivity of the cAMP antiserum with cyclic GMP was $<0.00008 \%$, as indicated in the technical information with the cAMP $\left[{ }^{125}\right.$ I]RIA kit (obtained from New England Nuclear).

To assay $\beta$-adrenergic receptors, the cells were prepared for assay by washing twice with $0.05 \mathrm{~m}$ Tris-buffered saline, $\mathrm{pH} 7.4$, and scraping with a rubber policeman. (Trypsin cannot be used because of the sensitivity of the $\beta$-adrenergic receptor to proteolytic degradation.) The cell suspension was then centrifuged at $150 \mathrm{~g}$ and the pellet resuspended to approximately $30 \mathrm{mg}$ protein $/ \mathrm{ml}$. $\beta$-Adrenergic receptors were measured by a competitive binding assay with the potent $\beta$-adrenergic antagonist, $\left[{ }^{3} \mathrm{H}\right]$ dihydroalprenolol $\left(\left[{ }^{3} \mathrm{H}\right] \mathrm{DHA}\right)$, essentially as described by Mukherjee and Lefkowitz (9). The reaction was carried out in a total volume of 500 $\mu \mathrm{l}$, containing $400 \mu \mathrm{l}$ cell suspension, $10 \mathrm{~nm}\left[{ }^{3} \mathrm{H}\right] \mathrm{DHA}$, and either $10 \mu \mathrm{M}$ $( \pm$ ) propranolol or an equivalent amount of buffer. The assay was incubated for $10 \mathrm{~min}$ at $37^{\circ} \mathrm{C}$ and terminated by adding ice-cold Tris buffer and emptying the sample over a Whatman GF/C filter. The filters were washed thoroughly with buffer, dried, and counted in Instagel scintillation fluid. Protein content was determined by the method of Lowry et al. (8). The spccific binding, expressed as femtomoles per microgram protein, was calculated as the difference between total binding $\left({ }^{3} \mathrm{H}\right] \mathrm{DHA}$ only) and nonspecific binding $\left(\left[{ }^{3} \mathrm{H}\right] \mathrm{DHA}\right.$ and excess propranolol).

Plasma membranes were prepared from both the CF and normal fibroblasts, essentially as described by Kartner et al. (10). The cells were washed four times with $20 \mathrm{ml}$ PBS and swollen with $25 \mathrm{ml}$ of $1 \mathrm{~mm}$ $\mathrm{NaHCO}_{3}, \mathrm{pH} 7.4$, for $1 \mathrm{~min}$ at room temperature. This hypotonic procedure was repeated and the cells were removed from the surface by manual shaking. The cell suspension was made $0.5 \mathrm{~mm}$ in EDTA, pH 7.4 , and centrifuged for $20 \mathrm{~min}$ at $27,000 \mathrm{~g}$. The resulting pellet was resuspended in $5 \mathrm{ml}$ of $10 \%(\mathrm{w} / \mathrm{v})$ sucrose, layered on a discontinuous density gradient made up of $5 \mathrm{ml}$ each of 30,48 , and $60 \%$ sucrose, and centrifuged at $76,000 \mathrm{~g}$ for $2 \mathrm{hr}$ in a SW27.1 rotor. Material banding at the interfaces was collected by aspiration, washed free of sucrose with 
$1 \mathrm{~mm} \mathrm{NaHCO}_{3}, \mathrm{pH} 7.4$, and centrifuged at $33,000 \mathrm{~g}$ for $20 \mathrm{~min}$. The fraction from the 10-30 interface was reported to contain plasma membranes (10) and this fraction was used in subsequent binding studies with both $\mathrm{CF}$ and normal lines.

\section{RESULTS}

We could consistently distinguish CF fibroblasts from normal lines when presented "blind" and as pairs. Under these conditions, CF fibroblasts showed 1.5- to 2.5-fold greater induction of cAMP compared to normal fibroblasts after incubating the cells with $10^{-5} \mathrm{M}$ metaproterenol, an analog of isoproterenol (Table 1). There was some overlap in the actual values from experiment to experiment, but within any one experiment there was always an increased induction of cAMP in the CF fibroblasts.

The time dependency of $\left[{ }^{3} \mathrm{H}\right]$ dihydroalprenolol $\left(\left[{ }^{3} \mathrm{H}\right] \mathrm{DHA}\right)$ binding was performed in the presence and absence of a large excess of unlabeled propranolol and specific binding (total nonspecific) was found to be optimal after $10 \mathrm{~min}$ at $37^{\circ} \mathrm{C}$. This time was used in all further experiments. Saturation experiments were performed using varying concentrations of $\left[{ }^{3} \mathrm{H}\right] \mathrm{DHA}(2-40 \mathrm{nM})$ with both cell types. The saturation curve obtained using normal cells, shown in Fig. 1, appears to plateau at approximately 10 nм $\left[{ }^{3} \mathrm{H}\right] \mathrm{DHA}$. That obtained with the CF cells, however, shown in Fig. 2, did not reach saturation at the hormone concentrations used. This

TABLE 1

Induction of camp in Fibroblasts from CF Patients and Normal Controls with METAPROTERENOL

\begin{tabular}{lccccc} 
& & & \multicolumn{2}{c}{ cAMP (pmole/mg protein) } & \\
Treatment & Cell line & Expt & Uninduced & Induced & $\begin{array}{c}n \text {-Fold } \\
\text { induction }\end{array}$ \\
\hline Metaproterenol & $\mathrm{Nl}^{a}$ & 1 & 11.65 & 18.68 & 1.6 \\
$\left(10^{-5}\right.$ M. 30 min) & $1348-\mathrm{CF}$ & 1 & 12.48 & 33.56 & 2.7 \\
& $\mathrm{Nl}$ & 2 & 21.30 & 15.54 & 0.7 \\
& $1348-\mathrm{CF}$ & 2 & 10.92 & 13.28 & 1.2 \\
& $\mathrm{Nl}$ & 3 & 7.49 & 11.16 & 1.5 \\
& $1348-\mathrm{CF}$ & 3 & 7.48 & 15.08 & 2.0 \\
& $\mathrm{Nl}$ & 1 & 9.75 & 16.24 & 1.7 \\
& $770-\mathrm{CF}$ & 1 & 10.76 & 23.83 & 2.2 \\
& $\mathrm{Nl}$ & 2 & 14.63 & 21.26 & 1.4 \\
& $770-\mathrm{CF}$ & 2 & 7.12 & 21.75 & 3.0 \\
& $\mathrm{Nl}$ & 3 & 3.96 & 8.39 & 2.1 \\
& $770-\mathrm{CF}$ & 3 & 1.54 & 6.00 & 3.9 \\
& & & & &
\end{tabular}

Note. $t=2.4 ; P<0.05$.

"Normal cell line. 


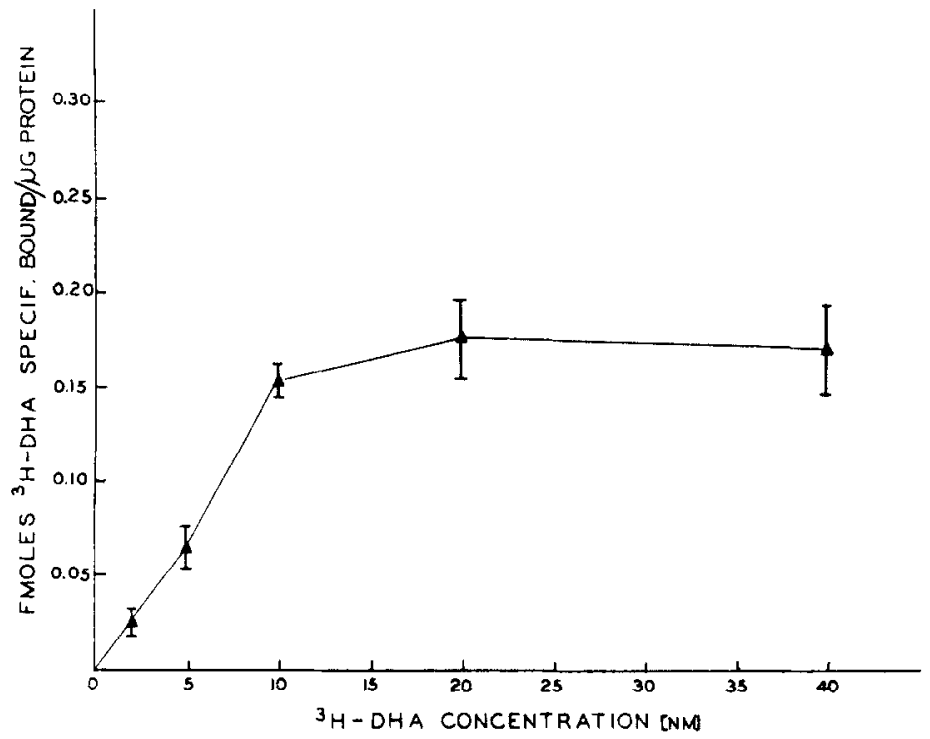

Fig. 1. Saturation curve for normal fibroblasts at varying concentrations of $\left[{ }^{3} \mathrm{H}\right]$ dihydroalprenolol.

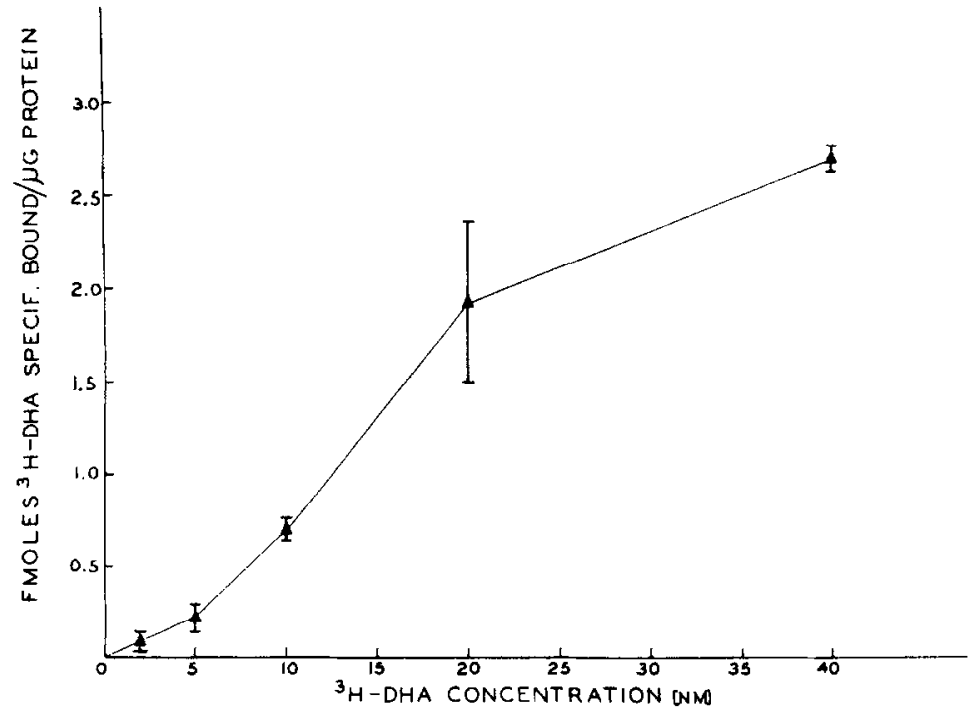

Fig. 2. Saturation curve for cystic fibrosis fibroblasts at varying concentrations of $\left[{ }^{3} \mathrm{H}\right]$ dihydroalprenolol. 
suggests a difference in affinity between the CF and normal fibroblast $\beta$-adrenergic receptor but, due to assay variation, a Scatchard plot was not meaningful. Saturation studies using $\left[{ }^{3} \mathrm{H}\right]$ dihydroalprenolol on several tissues indicate the apparent equilibrium dissociation constant, $K_{D}$, to be 12-15 nM (11). We decided to continue to compare normal and $\mathrm{CF}$ fibroblast binding of $\left[{ }^{3} \mathrm{H}\right] \mathrm{DHA}$ at $10 \mathrm{~nm}$, this concentration being below the $K_{D}$, since the normal receptor was saturated at this concentration and it has been the usual concentration used on a variety of cell types.

The mean "specific binding" for each CF and normal line as well as the cumulative means when assayed at the standardly used concentration of $10 \mathrm{nM}$, are shown in Table 2. The threefold increase in CF cells is statistically significant by Student's $t$ test $(P<0.001)$. Although we have found some overlap between $C F$ and normal lines from one experiment to another, on a given day, the CF lines consistently showed increased $\beta$-adrenergic binding compared to normal cells. This is clearly shown by the $\mathrm{CF} / \mathrm{N}$ ratio for each experiment, given in Table 3 , and is significant by the Wilcoxon rank sum test at $P=0.0011$.

To confirm that we are dealing with cell surface receptors, $\beta$-adrenergic binding was measured on purified plasma membranes of $C F$ and normal

TABLE 2

Specific Binding to $\beta$-Adrenergic Receptors in Cystic Fibrosis and Normal Fibroblasts

\begin{tabular}{lccc}
\hline Line & $\bar{X}$ & SF & $n$ \\
\hline GM2801 & 0.46 & 0.06 & 4 \\
GM1959 & 0.65 & 0.32 & 3 \\
GM770 & 0.88 & 0.18 & 5 \\
GM0768 & 1.82 & 1.39 & 2 \\
GM1958 & 0.38 & - & 1 \\
GM1957 & 0.51 & - & 1 \\
CF-PH & 0.44 & 0.03 & 2 \\
Total & 0.73 & 0.12 & 18 \\
872 & 0.21 & 0.12 & 2 \\
NF-C & 0.10 & 0.05 & 2 \\
NF-D & 0.14 & 0.03 & 1 \\
NF-F & 0.46 & - & 7 \\
MODY-I & 0.18 & 0.06 & 3 \\
MODY-F & 0.29 & 0.06 & 3 \\
MODY-E & 0.11 & 0.05 & 1 \\
MODY-III & 0.13 & $-\overline{0}$ & 2 \\
RC-N & 0.63 & 0.01 & 29 \\
Total & 0.25 & 0.03 & - \\
\hline
\end{tabular}

Note. $t(45)=0.0949 ; P=0.001$. 
TABLE 3

Specific Binding Ratio-Cystic Fibrosis to

NORMAL

\begin{tabular}{lc}
\hline Expt & CF/N ratio \\
\hline 1 & 6.36 \\
2 & 2.50 \\
3 & 2.80 \\
4 & 4.21 \\
5 & 3.27 \\
6 & 2.14 \\
7 & 8.12 \\
8 & 1.58 \\
9 & 2.67 \\
\hline
\end{tabular}

Note. $P\left(w_{s} \geqslant 120\right)=0.0011$.

fibroblasts (Table 4). The membrane extracts from CF fibroblasts showed $7.15 \pm 0.16 \mathrm{fmole} / \mu \mathrm{g}$ protein specifically bound while those from normal cells showed $2.7 \pm 0.65 \mathrm{fmole} / \mu \mathrm{g}$ protein. The 10 -fold enrichment in $\beta$ adrenergic receptor in plasma membranes in both cases argues that the difference between $\dot{C}$ F and normal fibroblasts is not due to differences in compartmentalization of receptor.

\section{DISCUSSION}

There is increased stimulation of several types of autonomic nervous system glands such as the salivary gland in patients with CF $(12,13)$. Evidence suggests that the altered exocrine secretions in these patients could be due to altered autonomic nervous system receptors in exocrine cells (14). Cultured skin fibroblasts from patients with CF seem to exhibit this altered membrane property. We have found a greater induction of cAMP in CF fibroblasts than in normal fibroblast cells when they are

TABLE 4

Specific Binding on Purified Plasma Membranes from Cystic Fibrosis and Normal

Fibroblasts

\begin{tabular}{lcc}
\hline & CF & Normal \\
\hline & 6.99 & 3.04 \\
& 7.31 & 1.39 \\
Total $\bar{X}$ & 7.15 & 2.07 \\
SE & 0.16 & 2.17 \\
\hline
\end{tabular}

Note. $t(3)=7.90 ; P=0.01$. 
incubated with $\beta$-adrenergic agonists. The CF fibroblasts, therefore, exhibit "supersensitivity" to $\beta$-adrenergic agonists with respect to normal fibroblast cells. The increased response could, a priori, be due to several factors, such as increased amount of $\beta$-adrenergic receptors, increased adenylate cyclase activity, or decreased PDE activity. The accompanying paper (15) shows that the high $K_{m}$ form of cAMP phosphodiesterase is increased, not decreased. Thus, we measured specific binding of the $\beta$ adrenergic antagonist, $\left[{ }^{3} \mathrm{H}\right]$ dihydroalprenolol. Although the saturation kinetics of binding were different in $\mathrm{CF}$ and normal fibroblasts, consistently more $\left[{ }^{3} \mathrm{H}\right] \mathrm{DHA}$ was bound by $\mathrm{CF}$ than by normal fibroblasts when assayed at the standard concentration of $10 \mathrm{~nm}$. This difference in binding was also found in the approximately 10-fold-enriched plasma membrane fraction. Buckwald and Riordan (16) did not find an increase in $\beta$-adrenergic receptors when studied on fibroblasts attached to plastic.

Although our, and some other, studies suggest increased $\beta$-adrenergic sensitivity, in vivo studies and studies on lymphocytes have suggested decreased production of cAMP in cystic fibrosis: when corrected to cyclic GMP excretion, cystic fibrosis patients secreted less cAMP in urine than did normal controls (17), were less sensitive to isoproterenolstimulated increases in blood pressure (18), and CF lymphocytes showed a decreased response of cAMP to isoproterenol stimulation (19). In this regard, it may be that fibroblasts are more similar to the pupil of the eye which shows increased responses to both adrenergic and cholinergic agonists in vivo (18). The decreased responses of cardiac muscle and lymphocytes to isoproterenol might also reflect down regulation of $\beta$ adrenergic receptors.

\section{SUMMARY}

We have found that cAMP is induced to a greater extent in cultured cystic fibrosis fibroblast cell lines than in normal lines using a $\beta$-adrenergic agonist. By using the potent $\beta$-antagonist, $\left[{ }^{3} \mathrm{H}\right]$ dihydroalprenolol in a competitive radioligand binding assay, we measured $\beta$-adrenergic specific binding on skin fibroblasts derived from cystic fibrosis patients and normal individuals. The $C F$ cells were found to have $0.73 \pm 0.12$ fmole/ $\mu \mathrm{g}$ protein specifically bound, while normal cells showed $0.25 \pm$ $0.03 \mathrm{fmole} / \mu \mathrm{g}$ protein. Even though this difference is highly statistically significant, we found some overlap between the two cell types from one experiment to another. In any given experiment, however, the CF cells consistently showed increased $\beta$-adrenergic binding when compared to normal controls. Binding was measured on plasma membrane extracts from CF and normal fibroblasts. The CF lines continued to show increased specific binding compared to normal lines when partially purified plasma membranes were assayed. The $\beta$-adrenergic binding capacity of 
partially purified plasma membranes was significantly higher (10 times) than the values obtained with whole cells in both cases.

\section{ACKNOWLEDGMENTS}

This work was supported by Grant 007 from ROFFG and a student fellowship to J. M. from the National Cystic Fibrosis Foundation. We thank Mrs. Rena Jones for excellent secretarial assistance.

\section{REFERENCES}

1. Buchwald, M., Proc. Nat. Acad. Sci. USA 73, 2899 (1976).

2. Roscher, A. A., Schmid, A. J., Hadorn, B., and Weissmann, U. N., Pediatr. Res. 14, $261(1980)$.

3. Epstein, J., Breslow, J. L., Fitzsimmons, M. J., and Vayo, M. M., Somat. Cell Genet. 4, 451 (1978).

4. Buchwald, M., and Mapleson, J. L., Mod. Prob. Paediatr. 19, 165 (1977).

5. Davis, P. B., Hill, S. C., and Ulane, M. M., Pediatr. Res. 14, 863 (1980).

6. Manganiello, V. C., and Breslow, J., Biochim. Biophys. Acta 362, 509 (1974).

7. Gilman, A. G., Proc. Nat. Acad. Sci. USA 67, 305 (1970).

8. Lowry, O. H., Rosebrough, N. J., Farr, A. L., and Randall, R. J., J. Biol. Chem. 193, 265 (1951).

9. Mukherjee, C., and Lefkowitz, R. J., Life Sci. 19, 1897 (1976).

10. Kartner, N., Alton, N., Swift, M., Buchwald, M., and Riordan, J. R., Membrane Biol. 36, 191 (1977).

11. Williams, L. T., and Lefkowitz, R. J., "Receptor Binding Studies in Adrenergic Pharmacology," Raven Press. New York, 1978.

12. Blomfield, J., Warton, K. L., and Brown, J. M., Arch. Dis. Child. 48, 267 (1973).

13. Chernick, W. Y., J. Biol. Chem. 246, 2859 (1971).

14. Mangos, J. A., Pediatr. Res. 10, 357 (1976).

15. Gnegy, M. E., Erickson, R. P., and Markovac, J., Biochem. Med. 26, 294 (1981).

16. Buchwald, M., and Riordan, J. R., Advan. Cyclic Nucleotide Res. 12, 243 (1980).

17. Murad. F., Moss, W. W., Johanson, A. J., and Selden, R. F., J. Clin. Endocrinol. Metabol. 40, 552 (1975).

18. Davis, P. B., Shelhamer, J. R., and Kaliner, M., N. Engl. J. Med. 302, 1453 (1980).

19. Davis, P. B., Braunstein, M., and Jay, C., Pediatr. Res. 12, 703 (1978). 